\title{
CHEK2 Gene Mutation
}

National Cancer Institute

\section{Source}

National Cancer Institute. CHEK2 Gene Mutation. NCI Thesaurus. Code C40458.

A change in the nucleotide sequence of the CHEK2 gene. 